STCIDOC

Infer, Interpret \& Inspire Science
International Journal of Dentistry and Oral Science (IJDOS)

ISSN: $2377-8075$

\title{
Comparative Assessment Of Frequency Of Sugar Intake and Oral Hygiene Practices On Dental Caries Between South Indian and Malaysian Population
}

Research Article

Dhanraj Ganapathy ${ }^{1 *}$, Sivesh Sangar ${ }^{2}$, Delphine Priscilla Anthony ${ }^{3}$

${ }^{1}$ Professor and Head Department of Prosthodontics Saveetha Dental College and Hospitals, Saveetha Institute Of Medical and Technical Sciences, Saveetha University, Chennai - 77, India.

${ }^{2}$ Undergraduate Student Saveetha Dental College, Saveetha Institute of Medical and Technical Sciences, Chennai-77, India.

${ }^{3}$ Senior Lecturer, Department of Conservative Dentistry and Endodontics Saveetha Dental College, Saveetha Institute of Medical and Technical Sciences, Chennai-77, India.

\section{Abstract}

Aim: To compare the frequency of sugar intake and oral hygiene practices on dental caries between South Indian and Malaysian population.

Materials and Methods: A Cross-sectional study was conducted among South Indian and Malaysian Population. A total of 200 patients were randomly selected from two Malaysian Universities (Universiti Kebangsaan Malaysia \& Universiti Malaya), Kuala Lumpur and out patients from Saveetha dental college, Sri Ramachandra University which constituted the South Indian population. A self-administered questionnaire was used in the present study that had 13 questions. The questions ranged from general questions related to intake and frequency of sweets/sugar consumption and also the frequency of tooth brushing. Data was entered in MS Excel sheet and was subjected to statistical analysis using IBM SPSS software version 20.0. Descriptive statistics were expressed by means of frequency and percentage. Chi-square test was performed to find the association between the variables.

Results: More than $65 \%$ of the patients who participated in the survey from both the age groups as well as countries agreed that they consume sugar before sleep. About $53 \%$ of the 18-29-year-old Malaysian and Indian population said that they only brush once daily where as in the other age group, $75 \%$ of the Indian population and $58.1 \%$ of the Malaysian population from the test group said that they only brush once daily.

Conclusion: The result of the study indicates that the sugar consumption by the older population of both countries is higher than the younger group. Out of the $80 \%$ of youths, around $60 \%$ have gotten fillings done. Out of the $67 \%$ of Indian population and $58 \%$ of the Malaysian who have visited the dentist, $78 \%$ and $88 \%$ of them respectively have gotten fillings done. Clinical Significance: Dental caries is the most prevalent disease, and is caused due to unhealthy nutritional habits and poor oral hygiene. The relationship between sugar intake, which includes the type of sugar being consumed in relation to the dietary intake of the patients and the oral hygiene assessment of the patients to the prevalence of Dental caries should be explained to the patient as a method of prevention or as a platform to reduce the severity and occurrence of Dental caries. Hence, the aim of this present study is to compare the frequency of sugar intake and occurrence of Dental caries in the South Indian population and Malaysian population.

Keywords: Dental Caries; Malaysian; South Indian; Sugars; Sweets.

\section{Introduction}

The relation between diet and nutrition and oral health and dis- ease can best be described as a synergistic 2-way street [1]. Diet has a local effect on oral health, primarily on the integrity of the teeth, $\mathrm{pH}$, and composition of the saliva and plaque. Nutrition,

*Corresponding Author:

Dhanraj Ganapathy,

Professor and Head, Department of Prosthodontics, Saveetha Dental College and Hospitals, Saveetha Institute Of Medical and Technical Sciences, Saveetha University, Chennai 77 , India.

Email Id: dhanraj@saveetha.com

Received: April 12, 2021

Accepted: May 08, 2021

Published: May 17, 2021

Citation: Dhanraj Ganapathy, Sivesh Sangar, Delphine Priscilla Anthony. Comparative Assessment Of Frequency Of Sugar Intake and Oral Hygiene Practices On Dental Caries Between South Indian and Malaysian Population. Int J Dentistry Oral Sci. 2021;08(05):2464-2469. doi: http://dx.doi.org/10.19070/2377-8075-21000484

Copyright: Dhanraj Ganapathy ${ }^{\circ} 2021$. This is an open-access article distributed under the terms of the Creative Commons Attribution License, which permits unrestricted use, distribution and reproduction in any medium, provided the original author and source are credited. 
however, has a systemic effect on the integrity of the oral cavity, including teeth, periodontium (supporting structure of the teeth), oral mucosa, and alveolar bone [2]. Alterations in nutrient intake secondary to changes in diet intake, absorption, metabolism, or excretion can affect the integrity of the teeth, surrounding tissues, and bone as well as the response to wound healing [3].

Sugars are present in drinks and food. The dental plaque forms continuously on the tooth surfaces, and when exposed to carbohydrates, bacteria present in the plaque form acid which reduces the $\mathrm{pH}$ in the mouth, which leads to demineralization of the teeth [1]. Over a period of time remineralisation occurs naturally, but when demineralization overlaps remineralisation, dental caries are formed on the tooth surface [4].

Many factors influence caries development, including the presence of plaque producing bacteria, innate susceptibility of tooth surfaces, and frequency of eating, oral hygiene maintenance, and availability of fluorides.

Diet and nutrition may interfere with the balance of tooth demineralization and remineralisation in several ways [5]. The diet provides sugars and other fermentable carbohydrates, which are metabolized to acids by plaque bacteria. Nutrition may affect both the anatomy and function of salivary glands. Chronic malnutrition may reduce the secretion rate of saliva and the buffer capacity of stimulated saliva but not that of unstimulated saliva. Malnutrition can adversely affect the volume, antibacterial properties, and physicochemical properties of saliva [6].

The salivary flow and its composition affect the balance of $\mathrm{Ph}$ levels in the tooth surfaces. Saliva contains minerals that increase the bacterial acids and promote demineralization. The more the salivary flow, the more rapid the demineralization it is the balance between acid production and salivary recovery that determines caries susceptibility [7]. The increasing availability of cariogenic foods to the public in the form of sweets, cookies, and chocolates is another cause for the increase in dental caries. Some investigators have reported that taste perceptions may be one of the major factors responsible for the amount, type, and frequency of sugar/ salt consumed [8].

So, the consumption of sugar in small amounts, along with other carbohydrates consumed frequently during the day will increase the caries risk rather than large amounts eaten. Sticky foods can stay in the mouth for longer periods, thus increasing the potential for caries [9]. Consumption of sugar containing foods is believed to be on the increase in developing countries, particularly among urban residents from higher socioeconomic background [10].

Dental caries is commonly measured by the sum of decayed, missing, and filled number of teeth (DMFT index)[11]. This value has been widely applied to assess the dental caries status at the population level for public health planning and policy-making purposes [12]. The DMFT index, first introduced by Klein et al., [13] is a cumulative caries measure, which indicates caries occurrence, including past and present dental caries [14]. The DMFT index has been in use for more than 76 years, and it remains the most commonly employed epidemiological index for assessing dental caries [15]. It has been suggested that variation in diet and oral hygiene habits can account for the social and regional distribution of caries experience [16]. However, this relationship appears to be converse in the developing countries [17].

We have numerous highly cited publications on well designed clinical trials and lab studies [18-30]. This has provided the right platforms for us to pursue the current study. Our aim is to compare the frequency of sugar intake and occurrence of Dental Caries in the South Indian population and Malaysian population.

\section{Materials and Methods}

The present study design was a cross-sectional study conducted among South Indian and Malaysian Population by a simple random probability sampling method. The study was conducted in both countries simultaneously from July 2018 to March 2019. The sample size was calculated manually based on the study done by Nivedha. V et al. The final sample size estimated was 200. A total of 200 patients were randomly selected from two Malaysian Universities (Universiti Kebangsaan Malaysia \& Universiti Malaya), Kuala Lumpur and outpatients from Saveetha dental college, Sri Ramachandra University which constituted the South Indian population. A written informed consent was obtained from all the participants who were willing to participate in the study with an ethical approval from the Institutional Review Board, Saveetha University. Ethical approvals were not obtained from the Malaysian Universities.

Inclusion criteria included generally healthy males and females aged 18 to 40 years of age, with at least $80 \%$ of teeth present and who were willing to undergo the study. Participants were informed priory about the need and reason for the study. Exclusion criteria were as follows: periodontitis, completely edentulous patients, multiple missing teeth, and patients hailing from outside the study area, any medical conditions that may interfere with study.

A descriptive study has been done in South India and in Malaysia for 200 patients who were divided in to two age groups. A selfadministered questionnaire was used in the present study that had 13 questions. The questions were closed ended and the language used to present the questionnaire to the patients was in English. The patients had to choose the answers from the multiple choices given to them. The questions ranged from general questions related to intake and frequency of sweets/sugar consumption and also the frequency of tooth brushing.

\section{The questionnaire included the following:}

\section{Demographic Details:}

Type Of Sugar Consumed: Snacks (cookies, candies, and chocolate), fruit juice, or other sugar containing drinks. The different forms are classified as hard sugar, soft sugar, and liquid sugar. Frequency of eating sweets: A question was included in our study where each child was asked. They were also questioned about the frequency of eating sweets. (once daily, 2-3 times a day, and more than 4 times a day). The individual was questioned regarding the brushing frequency. All the information was collected in a questionnaire from the individual who participated in the study.

The statistical analysis was done by data entry in MS Excel sheet and was subjected to statistical analysis using IBM SPSS software version 20.0. Descriptive statistics were expressed by means of 
frequency and percentage. Chi-square test was performed to find the association between the variables.

\section{Results}

In patients from the [18-29] (refer Table 1) age group, the most preferred sugar to be consumed are soft sugars that are chewable such as sweets and chewing gums which are consumed by $64.9 \%$ of Malaysians and $53.8 \%$ if the Indian population, this is followed by hard sugar and liquid sugars which have the same amount of consumption by the Indian population with $23.1 \%$. The Malaysian population however consumes more hard sugar than liquid sugar. In patients from the [30-43] age group (refer Table 2), the most preferred sugar to be consumed are also soft sugars with 45.8 percent of Indians and $37.2 \%$ of Malaysians consuming it. The second most consumed type of sugar by the Indian population is liquid sugar followed by hard sugar whereas in the Malaysian population of this age group, hard sugars are preferred over the consumption of liquid sugars.

The majority of the youth population of both Malaysia and India consumes 2-3 tablespoons of sugars on a daily basis. This result can be seen in the adult population as well. The adult population of Malaysia consumes 1-3 tablespoons of sugar on a daily basis. In both countries' age group, only a very minute number of people have a sugar intake of more than 4 times a day.

The preferred form of sugar consumed by the 18-29 age group are chocolates followed by sweets and fruit juices with $61.5 \%$ of the Indian population and $54.4 \%$ of the Malaysian population consuming chocolates. The preferred form of sugar consumed by the adult Malaysian population are chocolates with $46.5 \%$ followed by sweets, $32.6 \%$ and fruit juices, $20.9 \%$ whereas the form of sugar consumed by the adult Indian population are sweets with $37.5 \%$, followed by $35.4 \%$ of fruit juices and $27.1 \%$ of chocolates.

Sugars are consumed mostly every two hours for the youth population of Malaysia and India as well as the adult Malaysian population, with the patients in the 18-29 years age group consumes 2-4 tablespoons on a daily basis with the majority of adult Malaysian population who participated in the study consuming less than 2 tablespoons a day. However, the adult population in India tries to control their sugar consumption by limiting their sugar consumption to more than 4 hours daily with the majority of them consuming 2-4 tablespoons of sugar on a daily basis.

Table 1. Association between the South Indian and Malaysian population with the responses to the questions by the participants in the age group between $18-29$ years.

\begin{tabular}{|c|c|c|c|c|c|}
\hline \multicolumn{2}{|l|}{ Questions } & $\begin{array}{c}\text { South Indian } \\
\text { population } \\
(18-29 y r s)\end{array}$ & $\begin{array}{l}\text { Malaysian } \\
\text { population } \\
(18-29 \mathrm{yrs}) \\
\end{array}$ & Chi-square & $\mathrm{P}$ value \\
\hline \multirow{3}{*}{ Type of sugar consumed } & Hard sugar & $12(23.1 \%)$ & $14(24.6 \%)$ & \multirow{3}{*}{3.17} & \multirow{3}{*}{0.2} \\
\hline & Soft sugar & $28(53.8 \%)$ & $37(64.9 \%)$ & & \\
\hline & Liquid sugar & $12(23.1 \%)$ & $6(10.5 \%)$ & & \\
\hline \multirow{3}{*}{$\begin{array}{c}\text { Frequency of sugar consump- } \\
\text { tion }\end{array}$} & once daily & $20(38.6 \%)$ & $22(38.6 \%)$ & \multirow{3}{*}{0.46} & \multirow{3}{*}{0.98} \\
\hline & $\begin{array}{l}\text { two to three times } \\
\text { daily } \\
\end{array}$ & $28(53.8 \%)$ & $30(52.6 \%)$ & & \\
\hline & $\begin{array}{c}\text { more than } 4 \text { times } \\
\text { daily }\end{array}$ & $4(7.7 \%)$ & $5(8.8 \%)$ & & \\
\hline \multirow{3}{*}{$\begin{array}{l}\text { Time interval between con- } \\
\text { sumption of sugar }\end{array}$} & every 2 hours & $14(26.9 \%)$ & $17(29.8 \%)$ & \multirow{3}{*}{0.68} & \multirow{3}{*}{0.71} \\
\hline & every 4 hours & $32(61.5 \%)$ & $31(54.4 \%)$ & & \\
\hline & $\begin{array}{l}\text { more than } 4 \\
\text { hours }\end{array}$ & $6(11.5 \%)$ & $9(15.8 \%)$ & & \\
\hline \multirow{3}{*}{$\begin{array}{c}\text { Average quantity of sugar } \\
\text { consumed by the patient on a } \\
\text { daily basis }\end{array}$} & $\begin{array}{l}\text { less than } 2 \text { table- } \\
\text { spoons }\end{array}$ & $30(57.7 \%)$ & $28(49.1 \%)$ & \multirow{3}{*}{0.82} & \multirow{3}{*}{0.66} \\
\hline & 2-4 tablespoons & $14(26.9 \%)$ & $19(33.3 \%)$ & & \\
\hline & $\begin{array}{l}\text { more than } 4 \\
\text { tablespoons }\end{array}$ & $8(15.4 \%)$ & $10(17.5 \%)$ & & \\
\hline \multirow{2}{*}{$\begin{array}{l}\text { Does the patient consume } \\
\text { sugar before sleep }\end{array}$} & yes & $35(67.3 \%)$ & $39(68.4 \%)$ & \multirow{2}{*}{0.15} & \multirow{2}{*}{0.9} \\
\hline & no & $17(32.7 \%)$ & $18(31.6 \%)$ & & \\
\hline \multirow{2}{*}{ Frequency of brushing } & yes & $28(53.8 \%)$ & $30(52.6 \%)$ & \multirow{2}{*}{0.16} & \multirow{2}{*}{0.9} \\
\hline & no & $24(46.2 \%)$ & $27(47.4 \%)$ & & \\
\hline \multirow{2}{*}{$\begin{array}{c}\text { Does the patient have any } \\
\text { awareness pertaining to tooth } \\
\text { decay }\end{array}$} & yes & $36(69.2 \%)$ & $43(75.4 \%)$ & \multirow[b]{2}{*}{0.53} & \multirow[b]{2}{*}{0.47} \\
\hline & no & $16(30.8 \%)$ & $14(24.6 \%)$ & & \\
\hline \multirow{2}{*}{$\begin{array}{l}\text { Has the patient visited the } \\
\text { dentist before }\end{array}$} & yes & $42(80.8 \%)$ & $48(84.2 \%)$ & \multirow{2}{*}{0.22} & \multirow{2}{*}{0.64} \\
\hline & no & $10(19.2 \%)$ & $9(15.8 \%)$ & & \\
\hline
\end{tabular}


Table 2. Association between the South Indian and Malaysian population with the responses to the questions by the participants in the age group between $30-45$ years.

\begin{tabular}{|c|c|c|c|c|c|}
\hline \multicolumn{2}{|l|}{ Questions } & $\begin{array}{c}\text { South } \\
\text { Indian } \\
\text { population } \\
(30-45 \mathrm{yrs})\end{array}$ & $\begin{array}{l}\text { Malaysian } \\
\text { population } \\
(30-45 y r s)\end{array}$ & $\begin{array}{l}\text { Chi- } \\
\text { square }\end{array}$ & $\mathrm{P}$ value \\
\hline \multirow{3}{*}{ Type of sugar consumed } & Hard sugar & $10(20.8 \%)$ & $14(32.6 \%)$ & \multirow{3}{*}{1.66} & \multirow{3}{*}{0.44} \\
\hline & Soft sugar & $22(45.8 \%)$ & $16(37.2 \%)$ & & \\
\hline & Liquid sugar & $16(33.3 \%)$ & $13(30.2 \%)$ & & \\
\hline \multirow{3}{*}{ Frequency of sugar consumption } & once daily & $23(47.9 \%)$ & $19(44.2 \%)$ & \multirow{3}{*}{3.12} & \multirow{3}{*}{0.21} \\
\hline & two to three times daily & $14(29.2 \%)$ & $19(44.2 \%)$ & & \\
\hline & more than 4 times daily & $11(22.9 \%)$ & $5(11.6 \%)$ & & \\
\hline \multirow{3}{*}{$\begin{array}{l}\text { Time interval between consumption of } \\
\text { sugar }\end{array}$} & every 2 hours & $18(37.5 \%)$ & $18(41.9 \%)$ & \multirow{3}{*}{4.07} & \multirow{3}{*}{0.13} \\
\hline & every 4 hours & $10(20.8 \%)$ & $15(34.9 \%)$ & & \\
\hline & more than 4 hours & $20(41.7 \%)$ & $10(23.3 \%)$ & & \\
\hline \multirow{3}{*}{$\begin{array}{c}\text { Average quantity of sugar consumed by } \\
\text { the patient on a daily basis }\end{array}$} & less than 2 tablespoons & $20(41.7 \%)$ & $18(41.9 \%)$ & \multirow{3}{*}{5.51} & \multirow{3}{*}{0.06} \\
\hline & 2-4 tablespoons & $23(47.9 \%)$ & $13(30.2 \%)$ & & \\
\hline & more than 4 tablespoons & $5(10.4 \%)$ & $12(27.9 \%)$ & & \\
\hline \multirow{2}{*}{$\begin{array}{l}\text { Does the patient consume sugar before } \\
\text { sleep }\end{array}$} & yes & $32(66.7 \%)$ & $29(67.4 \%)$ & \multirow{2}{*}{0.01} & \multirow{2}{*}{0.94} \\
\hline & no & $16(33.3 \%)$ & $14(32.6 \%)$ & & \\
\hline \multirow{2}{*}{ Frequency of brushing } & yes & $36(75.0 \%)$ & $25(58.1 \%)$ & \multirow{2}{*}{2.92} & \multirow{2}{*}{0.09} \\
\hline & no & $12(25.0 \%)$ & $18(41.9 \%)$ & & \\
\hline \multirow{2}{*}{$\begin{array}{c}\text { Does the patient have any awareness } \\
\text { pertaining to tooth decay }\end{array}$} & yes & $26(54.2 \%)$ & $29(67.4 \%)$ & \multirow{2}{*}{1.67} & \multirow{2}{*}{0.2} \\
\hline & no & $22(45.8 \%)$ & $14(32.6 \%)$ & & \\
\hline \multirow{2}{*}{$\begin{array}{l}\text { Has the patient visited the dentist } \\
\text { before }\end{array}$} & yes & $32(66.7 \%)$ & $25(58.1 \%)$ & \multirow{2}{*}{0.71} & \multirow{2}{*}{0.40} \\
\hline & no & $16(33.3 \%)$ & $18(41.9 \%)$ & & \\
\hline
\end{tabular}

The majority of the patients in both age groups have said yes to consuming aerated drinks with $67.3 \%$ of the Indians and $64.9 \%$ of Malaysians in the 18-29 years old age group as well as $72.9 \%$ of Indians and $72.1 \%$ of Malaysians in the $30-45$ years age group. The average household confectionary expenditure on a monthly basis for an Indian youth is less than 5 USD where as the average household confectionary expenditure on a monthly basis for a Malaysian youth is between 5-10 USD [31]. The adult Indian households mostly spend about less than 5 USD a month with the second highest expenditure rate being between 5-10 USD. For a Malaysian adult, there's an equal amount of choices between less than 5 USD and 5-10 USD.

More than $65 \%$ of the patients who participated in the survey from both the age groups as well as countries agreed that they consume sugar before sleep. About $53 \%$ of the 18 -29-year-old Malaysian and Indian population said that they only brush once daily where as in the other age group, $75 \%$ of the Indian population and $58.1 \%$ of the Malaysian population from the test group said that they only brush once daily [32]. The awareness pertaining to tooth decay is higher in the younger group of people compared to the older group, demonstrating that the advent of social media has greatly influenced the youth regarding the importance of oral hygiene. This can also be confirmed by the following question with more than $80 \%$ of the youths have visited the dentist before but only $67 \%$ of the Indian adults and $58 \%$ of Malaysian adults have visited the dentist before. Out of the $80 \%$ of youths, around $60 \%$ have gotten fillings done. Out of the $67 \%$ of Indian population and $58 \%$ of the Malaysian who have visited the den- tist, $78 \%$ and $88 \%$ of them respectively have gotten fillings done.

\section{Discussion}

Caries prevalence varies from country to country and from region to region in the same country. Geographic variables such as, climate, diet, culture, and economic factors also affect the caries prevalence [33]. Besides this, an attempt has been made to compare the findings of the present study with the findings of other studies from with in and outside the country [34]. Food habits play an important role in the causation of dental caries [35, 36]. The introduction of refined sugar (sucrose) into the modern diet has been associated with increased caries prevalence [37]. In the present study, an effort was made to find the relationship between the type of sugar consumed, the frequency of sugar consumed, and brushing habits. Based on the present study, the value of DMFT increases with increased sugar intake [38, 39]. According to Nivedha. $\mathrm{V}$ et al it is necessary to evaluate a patient's dietary habits in order to propose a realistic change that may lead to the reestablishment of the balance between demineralization and remineralisation [40].

The limitations faced while conducting this study was that there were geographic restrictions as all the patients were from the same region visiting their nearest hospitals in both countries. Besides that, there was a problem getting data across between two countries. Another limitation encountered was in terms of ethnicity as the cases in our study consist of only a single racial distri- 
bution that can be found due to the geographical restriction in South India.

The future scope of exploration in regards to the frequency of sugar intake and oral hygiene practices on dental caries are by conducting a study with a bigger sample. Dental caries is the main problem caused in the oral cavity that can further lead to complications such as pulpitis, crown fractures as well as the tooth needing extraction if not treated soon enough. Prevention of dental caries has to be placed at an utmost importance to prevent further complications with the patients being educated on the effects of sugar intake and oral hygiene habits.

\section{Conclusion}

The result of the study indicates that the sugar consumption by the older population of both countries is higher than the younger group [41, 42]. Although the amount of sugar consumed before bed is around the similar amount for both groups, the awareness pertaining to tooth decay is higher in the younger group of people compared to the older group in both countries, demonstrating that the advent of social media has greatly influenced the youth in regards to the importance of oral hygiene [43]. This can also be confirmed by the following results with the number of youths who visited the dentist prior to this questionnaire being distributed is higher than the adults who have been to the dentist.

\section{References}

[1]. Fisher FJ. A field survey of dental caries, periodontal disease and enamel defects in Tristan da Cunha. Part 2. Methods and results. Brit. Dent. J.. 1968;125(10):447-53.

[2]. Shimamura S. [Incidence of caries in permanent teeth during a period of $20 \mathrm{~kg}$ annual sugar consumption per person in Japan]. Koku Eisei Gakkai Zasshi. 1974 Sep;24(3):228-34. Japanese. Pubmed PMID: 4534700.

[3]. Gibson S, Williams S. Dental caries in pre-school children: associations with social class, toothbrushing habit and consumption of sugars and sugar-containing foods. Further analysis of data from the National Diet and Nutrition Survey of children aged 1.5-4.5 years. Caries Res. 1999;33(2):101-13. Pubmed PMID: 9892777.

[4]. Scheinin A, Mäkinen KK, Ylitalo K. Turku sugar studies. V. Final report on the effect of sucrose, fructose and xylitol diets on the caries incidence in man. Acta Odontol Scand. 1976;34(4):179-216. Pubmed PMID: 795260.

[5]. Schnlerud A. Dental caries and nutrition during wartime in Norway. Fabritius; 1950.

[6]. Sheiham A. Dietary effects on dental diseases. Public Health Nutr. 2001 Apr;4(2B):569-91. Pubmed PMID: 11683551

[7]. Adenubi JO. Extraction of deciduous molars in pre-school and school children in Lagos. Nigerian Medical Journal. 1974;4:251-5.

[8]. PFAFFMANN C. The pleasures of sensation. Psychol Rev. 1960 Jul;67:25368. Pubmed PMID: 14432499.

[9]. Downer MC, Drugan CS, Blinkhorn AS. Correlates of dental caries in 12-year-old children in Europe: a cross-sectional analysis. Community Dent Health. 2008 Jun;25(2):70-8. Pubmed PMID: 18637317.

[10]. Ismail AI, Tanzer JM, Dingle JL. Current trends of sugar consumption in developing societies. Community Dent Oral Epidemiol. 1997 Dec;25(6):43843. Pubmed PMID: 9429817.

[11]. World Health Organization. The world health report 2000: health systems: improving performance. World Health Organization; 2000.

[12]. Jakobsen JR, Hunt RJ. Validation of oral status indicators. Community Dent Health. 1990 Sep;7(3):279-84. Pubmed PMID: 2076505.

[13]. Klein H, Palmer CE, Knutson JW. Studies on dental caries: I. Dental status and dental needs of elementary school children. Public Health Reports (1896-1970). 1938 May 13:751-65.

[14]. Diehnelt DE, Kiyak HA. Socioeconomic factors that affect international caries levels. Community Dent Oral Epidemiol. 2001 Jun;29(3):226-33. Pubmed PMID: 11409682

[15]. Broadbent JM, Thomson WM. For debate: problems with the DMF index pertinent to dental caries data analysis. Community Dent Oral Epidemiol.
2005 Dec;33(6):400-9. Pubmed PMID: 16262607.

[16]. Addo-Yobo C, Williams SA, Curzon ME. Oral hygiene practices, oral cleanliness and periodontal treatment needs in 12-year old urban and rural school children in Ghana. Community Dent Health. 1991 Jul;8(2):155-62. Pubmed PMID: 1878793.

[17]. Downer MC. Caries experience and sucrose availability: an analysis of the relationship in the United Kingdom over fifty years. Community Dent Health. 1999 Mar;16(1):18-21. Pubmed PMID: 10697350.

[18]. Ramarao S, Sathyanarayanan U. CRA Grid - A preliminary development and calibration of a paper-based objectivization of caries risk assessment in undergraduate dental education. J Conserv Dent. 2019 Mar-Apr;22(2):185-190. Pubmed PMID: 31142991.

[19]. Poorni S, Srinivasan MR, Nivedhitha MS. Probiotic Streptococcus strains in caries prevention: A systematic review. J Conserv Dent. 2019 MarApr;22(2):123-128. Pubmed PMID: 31142979.

[20]. Manohar MP, Sharma S. A survey of the knowledge, attitude, and awareness about the principal choice of intracanal medicaments among the general dental practitioners and nonendodontic specialists. Indian J Dent Res. 2018 Nov-Dec;29(6):716-720. Pubmed PMID: 30588997.

[21]. Azeem RA, Sureshbabu NM. Clinical performance of direct versus indirect composite restorations in posterior teeth: A systematic review. J Conserv Dent. 2018 Jan-Feb;21(1):2-9. Pubmed PMID: 29628639.

[22]. Jenarthanan S, Subbarao C. Comparative evaluation of the efficacy of diclofenac sodium administered using different delivery routes in the management of endodontic pain: A randomized controlled clinical trial. J Conserv Dent. 2018 May-Jun;21(3):297-301. Pubmed PMID: 29899633.

[23]. Nandakumar M, Nasim I. Comparative evaluation of grape seed and cranberry extracts in preventing enamel erosion: An optical emission spectrometric analysis. J Conserv Dent. 2018 Sep-Oct;21(5):516-520. Pubmed PMID: 30294113.

[24]. Malli Sureshbabu N, Selvarasu K, V JK, Nandakumar M, Selvam D. Concentrated Growth Factors as an Ingenious Biomaterial in Regeneration of Bony Defects after Periapical Surgery: A Report of Two Cases. Case Rep Dent. 2019 Jan 22;2019:7046203. Pubmed PMID: 30805222.

[25]. Siddique R, Sureshbabu NM, Somasundaram J, Jacob B, Selvam D. Qualitative and quantitative analysis of precipitate formation following interaction of chlorhexidine with sodium hypochlorite, neem, and tulsi. J Conserv Dent. 2019 Jan-Feb;22(1):40-47. Pubmed PMID: 30820081.

[26]. Teja KV, Ramesh S, Priya V. Regulation of matrix metalloproteinase-3 gene expression in inflammation: A molecular study. J Conserv Dent. 2018 NovDec;21(6):592-596. Pubmed PMID: 30546201.

[27]. Rajakeerthi R, Nivedhitha MS. Natural Product as the Storage medium for an avulsed tooth-A Systematic Review. Cumhuriyet Dental Journal. 2019;22(2):249-56.

[28]. Siddique R, Nivedhitha MS. Effectiveness of rotary and reciprocating systems on microbial reduction: A systematic review. J Conserv Dent. 2019 Mar-Apr;22(2):114-122. Pubmed PMID: 31142978.

[29]. Janani K, Ajitha P, Sandhya R, Teja KV. Chemical constituent, minimal inhibitory concentration, and antimicrobial efficiency of essential oil from oreganum vulgare against Enterococcus faecalis: An in vitro study. J Conserv Dent. 2019 Nov-Dec;22(6):538-543. Pubmed PMID: 33088061.

[30]. Khandelwal A, Palanivelu A. Correlation between dental caries and salivary albumin in adult population in Chennai: An in vivo study. Brazilian Dental Science. 2019 Apr 30;22(2):228-33.

[31]. Popkin BM. Nutrition in transition: the changing global nutrition challenge. Asia Pac J Clin Nutr. 2001;10 Suppl:S13-8. Pubmed PMID: 11708577.

[32]. Popkin BM. The nutrition transition and obesity in the developing world. J Nutr. 2001 Mar;131(3):871S-873S. Pubmed PMID: 11238777.

[33]. Sivaneswaran S, Barnard PD. Changes in the pattern of sugar (sucrose) consumption in Australia 1958-1988. Community Dent Health. 1993 Dec;10(4):353-63. Pubmed PMID: 8124623.

[34]. Popkin BM, Horton S, Kim S, Mahal A, Shuigao J. Trends in diet, nutritional status, and diet-related noncommunicable diseases in China and India: the economic costs of the nutrition transition. Nutr Rev. 2001 Dec;59(12):37990. Pubmed PMID: 11766908.

[35]. Forshee RA, Storey ML. The role of added sugars in the diet quality of children and adolescents. J Am Coll Nutr. 2001 Feb;20(1):32-43. Pubmed PMID: 11293466.

[36]. Krasse BO. Caries riskA Practical guide for assessment and control.

[37]. Naismith DJ, Nelson M, Burley V, Gatenby S. Does a high-sugar diet promote overweight in children and lead to nutrient deficiencies?. Journal of Human Nutrition and Dietetics. 1995 Aug;8(4):249-54.

[38]. Must A, Dallal GE, Dietz WH. Reference data for obesity: 85th and 95th percentiles of body mass index (wt/ht2) and triceps skinfold thickness. Am J Clin Nutr. 1991 Apr;53(4):839-46. Pubmed PMID: 2008861.

[39]. König KG, Schmid P, Schmid R. An apparatus for frequency-controlled feeding of small rodents and its use in dental caries experiments. Arch Oral 
Biol. 1968 Jan;13(1):13-26. Pubmed PMID: 5237553.

[40]. Rawal M, Malusare PC, PatilSoman B. Awareness and knowledge of oral cancer among dental practitioners of Bhopal, India-A cross-sectional study. Int J Oral Dent Health. 2018;4(2):056.

[41]. Must A, Dallal GE, Dietz WH. Reference data for obesity: 85th and 95th percentiles of body mass index (wt/ht2) - a correction. The American Journal of Clinical Nutrition. 1991 Nov 1;54(5):773-.
[42]. Hanley AJ, Harris SB, Gittelsohn J, Wolever TM, Saksvig B, Zinman B. Overweight among children and adolescents in a Native Canadian community: prevalence and associated factors. Am J Clin Nutr. 2000 Mar;71(3):693700. Pubmed PMID: 10702161.

[43]. Epstein LH, Wing RR, Valoski A. Childhood obesity. Pediatr Clin North Am. 1985 Apr;32(2):363-79. Pubmed PMID: 3887305. 